This item was submitted to Loughborough's Research Repository by the author.

Items in Figshare are protected by copyright, with all rights reserved, unless otherwise indicated.

\title{
Lost in transition: the transfer of lean manufacturing to construction
}

PLEASE CITE THE PUBLISHED VERSION

http://dx.doi.org/10.1108/09699980810886874

PUBLISHER

(c) Emerald Group Publishing Limited

VERSION

AM (Accepted Manuscript)

LICENCE

CC BY-NC-ND 4.0

REPOSITORY RECORD

Jorgensen, Bo, and Stephen Emmitt. 2019. "Lost in Transition: The Transfer of Lean Manufacturing to Construction". figshare. https://hdl.handle.net/2134/12199. 
This item was submitted to Loughborough's Institutional Repository (https://dspace.lboro.ac.uk/) by the author and is made available under the following Creative Commons Licence conditions.

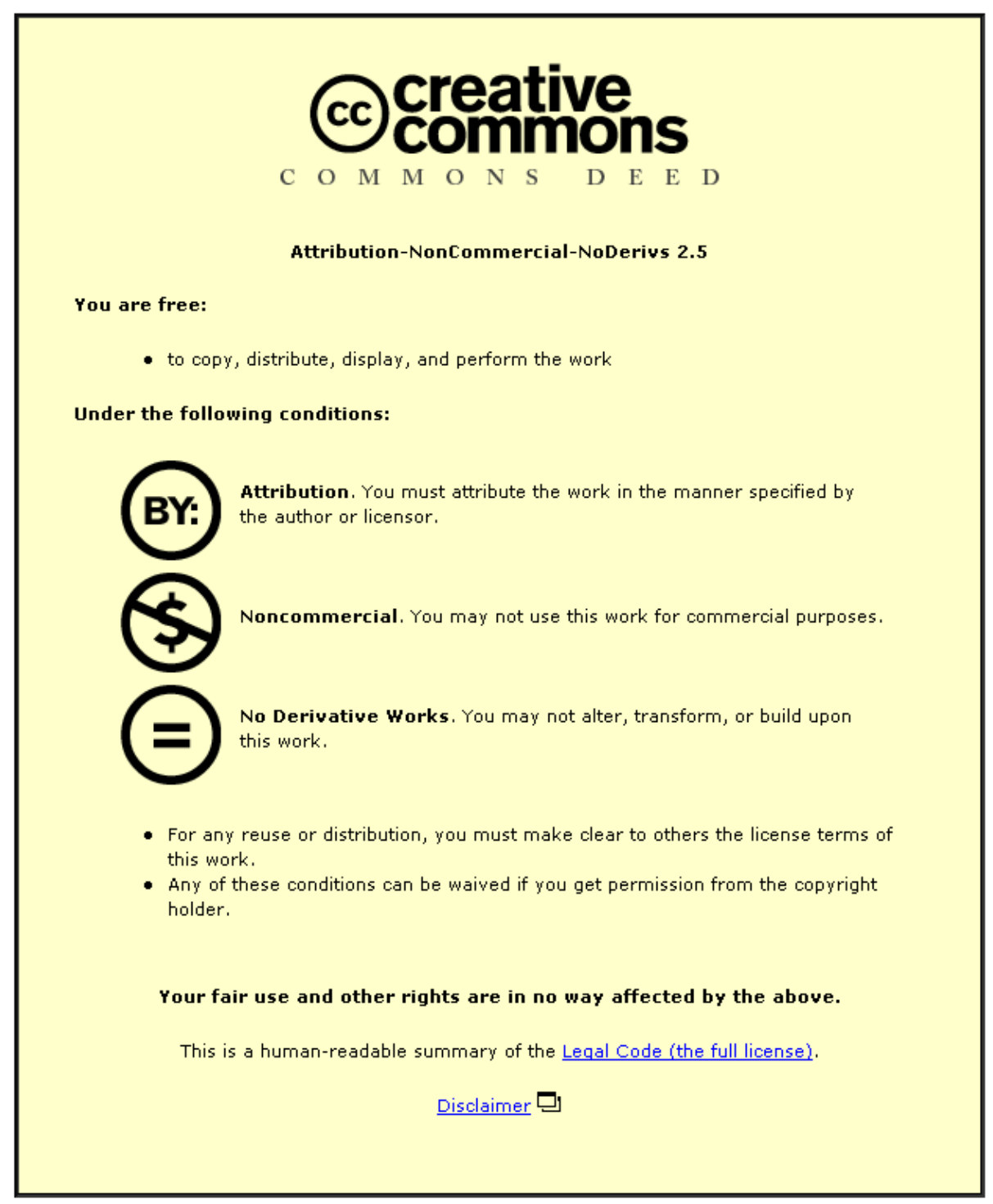

For the full text of this licence, please go to: http://creativecommons.org/licenses/by-nc-nd/2.5/ 


\title{
LOST IN TRANSITION - THE TRANSFER OF LEAN MANUFACTURING TO CONSTRUCTION
}

Bo Jørgensen, PhD, consultant engineer, ConProC, Copenhagen, Denmark. Email: BJ@conproc.com

Stephen Emmitt, PhD, professor, Department of Civil and Building Engineering, Loughborough University, Loughborough, LE11 3TU, UK.

Email: S.Emmitt@lboro.ac.uk

(Corresponding author)

\begin{abstract}
Purpose - The objective is to explore the transfer of lean manufacturing/production from the Japanese manufacturing industry to the construction sector in the west. Design/methodology/approach - Research literature from the fields of lean manufacturing/production and lean construction was reviewed. This revealed a number of characteristics that are specific to lean construction, most notably the recognition that critical research findings have been slow to emerge but appear to be gaining momentum.

Findings - In the transition from manufacturing to construction the process losses appear to be related to critical aspects and the challenges surrounding practical application to a different context. Lean is highly interpretive and there is no shared definition or understanding of what is meant by lean, lean production, and lean construction. The focus has been mainly on production system design, planning and management, and implementation. This narrow focus has meant that some important issues concerning the wider aspects of lean have been overlooked. There is a need for a 'back to basics' discussion on many other aspects of the approach, such as whole-life value and waste identification.

Research limitations/implications - The work is limited to an extensive literature review.

Originality/value - The extensive literature review makes an original contribution to the lean construction field and provides a valuable resource for researchers.

Keywords - Context, lean construction, lean manufacturing and production, transferability.

Paper type - Literature review
\end{abstract}




\section{LOST IN TRANSITION - THE TRANSFER OF LEAN MANUFACTURING TO CONSTRUCTION}

\section{INTRODUCTION}

Originally adopted from manufacturing the lean approach to construction has become an established theme within the architectural, engineering and construction (AEC) sector where it has been promoted as a means to increase productivity and project performance (e.g. via the Egan report, DETR, 1998). Although the promotion of lean construction (and to a lesser extent lean design in AEC) has been highly visible in countries such as the USA, UK and Denmark, critical debate has been scarce. Success stories reporting significant and even revolutionary results following the application of lean approaches, tools, and systems from volume manufacturing are common in the construction sector, although in many cases documentation is weak or absent. At the same time the proponents of lean construction have continued to ignore the extensive critical literature on lean manufacturing, a point repeatedly made by Green (1999a; 1999b; 2000; 2002) and Green \& May (2005). The failure to recognise the potentially dark side of lean (to borrow a phrase from Green) in the construction debate should be a cause for concern; the danger being that both researchers and practitioners are misled by an overly optimistic literature. However, as explored in this paper, the argument is not so clear cut.

It should be recognised that many of the concerns over lean production are contextually bound to application in manufacturing industries producing in volumes significantly higher than what is typical for construction. In manufacturing lean is typically applied with a focus on highly standardised, repetitive, production processes and on measures to achieve progressive decreases in lead time. Some of the criticisms made of the literature are not always relevant to the construction sector, where the focus is on projects and, with the exception of some repetitive building types, not high-volume production techniques. Thus many of the arguments (both positive and negative) raised in the lean production debate cannot simply be transposed to a (lean) construction context. The objective is to explore the transfer of lean manufacturing to construction, thus helping to establish the transparency needed for richer academic debate to develop. By reviewing the research literature on lean manufacturing and production as well as that in the lean construction field it was possible to highlight a number of characteristics that are specific to lean construction. These relate mainly to a focus on a few specific elements of the lean approach.

\section{Methodology}

A decision was taken to focus the review on 'research literature.' For the purpose of this paper the term research literature includes articles in peer reviewed journals, doctoral theses and research reports. Frequently cited popular (lean) management books are also included because of their influence on the development of the fields. A small number of papers published in conference proceedings were also included in our review because, as justified below, they appeared to be significant to the lean construction debate. 


\section{LEAN PRODUCTION AND MANUFACTURING}

An extensive body of research has discussed lean production and lean manufacturing as an approach to supply chain management, examined examples of its practical application, and/or investigated specific issues addressed by lean production. This body of research has acknowledged that measures promoted under the label of lean production/manufacturing (or the Toyota Production System) can be advantageous, depending on circumstances, and has substantially enriched the understanding of the impacts of lean production/manufacturing.

Much research has also been very critical regarding the credibility of the claims made by Ohno (1988), Shingo (1988), Womack et al. (1990), Womack \& Jones (1996) and several other proponents of lean, and the management principles applied by Toyota Motors in Japan (e.g. Berggren 1993; Jürgens 1995; Benders \& van Bijsterveld 2000 and Boyer \& Freyssenet; 2002). Claims for the general superiority of lean production over all other systems or approaches have been convincingly rejected and a number of negative side effects of lean production have been documented. The implicit assumption that the elimination of waste and enhancement of value is the most advantageous strategy for achieving market competitiveness and profitability cannot be generalised (e.g. Berggren 1992; Cusumano 1994; Katayama \& Bennett 1996). Indeed, the lean production model described by Womack et al. (1990) has never become the sole dominant production method of the Japanese industry, as is commonly claimed (e.g. Hines et al. 2004).

The importance of context has been widely ignored. It has been argued that lean production (which is a volume production method) provides an unsuitable approach for many manufacturers operating under conditions that do not fulfil the preconditions needed for the use of lean techniques (e.g Jürgens 1995; Lillrank 1995; Katayama \& Bennett 1996). Lean does not encompass the important influence of social and political institutions on enterprises and the procedures through which supply chains operate (Jürgens 1995; Williams et al. 1995; Cooney 2002). Some of the most influential publications, e.g. Womack and Jones (1996), whose recommendation is to 'Just do it!', have even explicitly disregarded the importance of context when promoting the general applicability and advantageousness of lean (e.g.Williams et al. 1995; Kieser 1997; Lewis 2000). For example Shingo (1988) argues that management must prevent the formation of labour unions, which does not sit comfortably within many western contexts.

The application of lean production in Japan and in the West has caused problems for the workforce, as documented in a number of studies. Research into working conditions and other HR aspects has revealed negative side effects resulting from lean production practices and Japanese management systems. Empirical studies have indicated that lean production procedures have come with a high price for Japanese industrial workers who work under very hard and stressful conditions and enjoy rights inferior to those of workers in western industrialised countries (e.g. Dohse et al. 1985; Briggs 1988; Sullivan 1992; Williams et al. 1995). Some of these less desirable characteristics have also transferred to the West, for example to lean car manufacturing in Wales (Morris \& Wilkinson 1995; Wilkinson et al. 1995). Increased pollution due to small but frequent just in time (JIT) delivery (Cusumano 1994; Katayama \& Bennett 1996) and the major 
lean producers' dominance and pressure upon the small suppliers are occasionally raised as being problematic.

A wider discussion concerns the overall theme of interpreting and transferring management innovations from Japan to the West. Research suggests the existence of a (significant) mismatch between the procedures and policies that Japanese companies are reported to practice and what is actually taking place (e.g. Wilkinson \& Oliver 1989; Sullivan 1992). Bearing in mind the diversity in perception and understanding of lean production, and given that the literature often serves as inspiration for management debate in the west, it could be argued that more attention should be given to the question of coherence between actual practices in Japan and the western perception of the Japanese production and management systems.

Another weakness of the publications describing practices of Japanese organisational concepts is that they generally do not report in sufficient detail how data has been collected, e.g. how observations have been weighted in comparison to information provided by company representatives. Books by Ohno (1988) and Shingo (1988; 1989) have been very influential and are still extensively cited, yet both make extensive use of anecdotal arguments and draw mainly on their own work. These are popular management books, although they are often cited as if they were 'research', which they clearly are not. Publications describing in most detail the data collection supporting their arguments (e.g. Womack et al. 1990; Cooper \& Slagmulder 1999) have relied heavily on information provided by the management of the organisations studied. They do not refer to any examples of rigorous research methods for validating the descriptions of the practices reported. This is important in relation to a discussion of the transfer of lean to construction, because well-known management books and lean production publications have, and continue to be, taken as the conceptual starting point for most lean construction publications. Thus one could argue that the foundations for many lean construction publications are not built on very strong ground. This is an issue that deserves more attention from researchers.

When considering the transfer of lean production (processes) to construction (projects) it is necessary to consider the main characteristics of organisational concepts. First, they leave considerable room for interpretation. Second, they promise performance improvements. Organisation concepts that become management fashions also tend to become de-coupled from their original meanings as they are diffused, interpreted, translated, adopted and adapted (Abrahamson 1996; Kieser 1997). This phenomenon has had significant impact on the diffusion of lean production, resulting not only in the term being de-coupled from its original meaning, now covering many different kinds of initiatives, but also in widespread rhetorical adoption often dominating over substantial adoption (Benders 1999; Benders \& van Bijsterveld 2000).

\section{Common elements}

In spite of the variety of meanings ascribed the label 'lean', there appears to be a few common elements:

- A focus on eliminating/reducing waste and sources of waste in relation to the delivery of artefacts or services that represent value to the end customer; 
- End customer preference is adopted as the reference for determining what is to be considered value and what is waste;

- Management of production and supply chain from a (customer) demand pull approach;

- Approaching production management through focus on processes and flows of processes;

- An (at least to some degree) application of a system's perspective for approaching issues of waste elimination/reduction.

The concept of customer is central to lean thinking. A main principle is to consider all downstream operations as customers, while value is defined only as perceived by the final/end customer (often referred to as the 'ultimate customer'). This involves some important implications when applying lean to construction, where 'end customers' are multiple and the construction client rarely can be considered the single ultimate customer. Another crucial aspect is time. Typically built artefacts deliver their value and generate their waste over a very long time perspective. This is contrasted to the definition of end customer value adopted by Womack \& Jones (1996, p.16) who state that value is "only meaningful when expressed in terms of a specific product (a good or a service, and often both at once) which meets the [end] customer's needs at a specific price at a specific time.” This, nevertheless, constitutes the single dominant reference to customer value in the lean literature. The implication for built artefacts is addressed in more detail below.

\section{LEAN IN A CONSTRUCTION CONTEXT}

Lean entered construction a couple of years after it had gained momentum in western manufacturing industries. Its application to the built environment was first discussed by Koskela (1992), who investigated what he (then) referred to as 'the new production philosophy' and its application to construction. In a later PhD thesis Koskela (2000) argued that efforts to improve production (of physical artefacts, e.g. buildings and other structures) suffer from the absence of a general theory of production, and he argued that such a theory would need to encompass three fundamental elements of transformation, process, and value. Koskela concluded that most production practice and research (in construction, manufacturing and other industries) has been dominated by a focus on addressing production simplistically from a transformation perspective, with process and value generation aspects being under-emphasised. Koskela's work formed the foundations for what has become known as lean construction. Early ideas were also adopted from lean manufacturing and production, as can be seen from Alarcón (1997) and some of the contributions from the $1^{\text {st }}$ International Workshop on Lean Construction (e.g. Koskela 1993; Tanskanen et al. 1993; Ballard 1993). Although Koskela's work is frequently cited, few have discussed the entire framework, preferring to concentrate on discrete aspects. The most dominant of these have parallels with the common features identified in lean manufacturing (bullet points above) and can be summarised under three themes.

1. Production planning, control and management.

Two issues have dominated this theme, namely the Last Planner System of Production Control (LPS) and questions regarding scheduling techniques and work structuring. 
Approaches and methods for addressing waste through reduction of variability and uncertainty, especially via the Last Planner System of Production Control (LPS), have been widely promoted and discussed (e.g. Ballard 1994; 2000; Ballard \& Howell 1998; 2003b). This appears to have become the most popular measure in applied initiatives, and in some local or national environments LPS has become largely synonymous with lean construction (Green \& May 2005) For example, Paez et al. (2005) conclude that daily huddle meetings and the LPS are essential aspects of lean construction because they deal with exceptions and uncertainty. LPS also features prominently in the relatively few publications on techniques for lean building design management (e.g. Koskela et al. 1997; Ballard 2000, Ballard 2002), thus further reinforcing the rather narrow interpretation of lean construction. A number of studies have discussed issues of activity scheduling and of structuring projects, assignments and tasks for the application of lean techniques to construction (design and production). For example structuring of task execution for optimising resource allocation (e.g. through optimising batch sizes and minimising buffers, inventories, and work in progress), achieving short production cycles etc. In the approach of the Toyota Production System and lean production this field is central to the pursuit of short lead times, continuous improvements. Examples include workflow scheduling and management (Tommelein et al. 1999; Kenley 2004), work structuring (Tsao 2005) and simulation of processes and of buffering and batching practices (Tommelein,1999; Alves \& Tommelein 2004).

2. Production system design and construction project design.

This theme is strongly connected to the one above. More general questions of how to structure construction projects (and recently also the degree to which these are to be approached as individual projects in the first place) have been a constant characteristic. Some examples are supply chain management topics (e.g. Vrijhoef \& Koskela 1999; 2000; Vrijhoef et al. 2003) and construction as a project-based production system (Ballard 2005; Vrijhoef \& Koskela 2005; Koskela \& Ballard 2006; Winch 2006).

\section{Implementation and application.}

Aspects of implementation and application of tools (the LPS in particular), but few have looked into the wider impacts of lean diffusion beyond project or company level. Examples include empirical studies reporting different findings regarding project or process performance in connection to lean initiatives (CIB 2002; Thomas et al. 2002, 2003; Alárcon et al. 2005), and qualitative studies investigating implementation and diffusion processes, reporting applied practice in comparison to formal procedures, identifying e.g. obstacles and possibilities regarding implementation. Recent examples are provided by Miller et al. (2002); Johansen et al. (2004); Jørgensen (2006).

A common feature appears to be the adoption of a project structure as the organisational basis for designing and making. It is also possible to see that there has been a development in debate, understanding and practice within the field, which appears to follow a similar pattern to the development of the lean production literature. An indicator of an evolving field is found in Koskela's work. Early works discussed lean production as applied to construction (see Koskela 1992; 1993) while later publications have focused on the more fundamental issues of developing a general theory for production (Koskela 2000; 2001; Koskela \& Kagioglou 2005), with lean construction addressed as a discipline inspired by, not copied from, lean production (Koskela et al. 
2002). Similar to the diffusion of lean thinking within the manufacturing sector (Hines et al., 2004), the interest in value started to gain momentum much later than the issues concerning production rationalisation; although this development in construction appears to be slower compared to other sectors. Figure 1 summarises the transfer of lean from manufacturing to construction.

\section{[Figure 1 to be inserted here]}

\section{Customer value}

An important implication of applying the lean philosophy to construction is the understanding of waste and value. In the lean terminology (as originally suggested by Ohno, 1988) value is understood very narrowly as consisting only of what the end customer perceives as representing value to him/her. Anything that does not directly add to this value is regarded waste. Consequently any process is wasteful, so it is appropriate to distinguish between waste that cannot be avoided but should be reduced as much as possible (type 1), and waste that in principle is not required for delivering the value requested (type 2) which should be eliminated. In the lean construction literature value is either unaddressed, or it is largely discussed in the context of the construction project (the process), not the resultant building (the product).

The concept of customer value poses a number of challenges when applied to the construction of a built artefact representing a long-term investment which may be in function for one hundred years or more and have a number of different owners and users. The lean philosophy is only meaningful in construction if value and waste are defined with reference to a whole-life perspective. From a practical perspective, questions of systematically enhancing value and eliminating waste become increasingly more complex the further one moves from production activities into the field of architectural design. Detailed discussion of customer value is outside the scope of this paper, however, it is important to highlight the fact that this does need to be addressed.

\section{LEAN CONSTRUCTION - THE LACK OF A COMMON DEFINITION}

A distinctive feature of the lean construction literature is the lack of commonly used definitions. In an extensive review of the lean construction terminology and definitions, Jørgensen (2006) found a wide range of interpretations; concluding that few authors had posited explicit and concise definitions, making it difficult to establish exactly what the term lean construction means. Jørgensen (2006) also found that the term 'lean design' was increasingly being applied (e.g. Koskela et al., 1997; Freire, J. \& Alarcón, L.F. 2002), although it too had a variety of meanings. The lack of a common definition for lean construction and 'leanness', has also been discussed by Green \& May (2005) who found that lean construction and lean production are "variously understood as a set of techniques, a discourse, a 'socio-technical paradigm' or even a 'cultural commodity'”. Based on an empirical study from the UK construction industry and interviews with authors of the Egan Report (DETR 1998), Green \& May suggest that three models represent the practical adoption of lean in construction: a lean model of waste 
elimination, partnering, and structuring the context. Their findings support the view that lean construction, while highly diverse in interpretation and application, is inspired by lean production rather than just a modified copy of it (as previously discussed by Koskela et al. 2002). Whether lean construction techniques are an extension of lean manufacturing or a diversion from it is, according to Paez et al. (2005, p.234), still an open question. A question that is difficult to answer given the wide range of meanings found in the literature. Green \& May conclude that the meaning of lean construction is continuously renegotiated within localised contexts. Of course, this observation could also be made of other approaches such as project partnering and supply chain management in construction (e.g. Fernie \& Thorpe 2007).

The importance of clear terminology, or rather the lack of it, is illustrated in an exchange of views following publication of a report by Thomas et al. (CIB 2002). In the report and two associated articles based on empirical studies (Thomas et al. 2002; 2003) it is argued that in construction the production throughput variability should be reduced to 'acceptable levels' and the remaining variability absorbed by flexible workforce management strategies. Flexible workforce strategies were found to be a more efficient alternative to reducing the variability of workflow, which according to (Thomas et al. 2002; 2003) has been overemphasised in lean construction. They concluded that lean construction should focus more on labour flow and workforce management strategies to achieve better labour performance.

The arguments and conclusion have been disputed by Howell et al. (2004) and (Ballard et al. (2005), and the critique subsequently rejected by Thomas et al. (2004; 2005). The exchange of views is marked by lengthy clarifications and obvious disagreement regarding what is meant by terms and definitions through which the arguments are presented. The very perception of labour resource is an issue of fundamental importance to discussions on the application of lean techniques, methods and approaches to construction management. If understanding production processes as involving a set of different flows, (according to the TFV theory (Koskela 2000) on which much of the discussion builds), it follows that the flow of labour cannot be considered a simple production parameter, like e.g. the flow of materials. This aspect is brought up by Ballard et al. (2005), emphasising that labour is not a commodity and should not be treated as such; thus they do not find the recommendation of applying flexible workforce capacity strategies ethically justifiable. The discussion has raised important issues regarding consequences for health/safety and work/employment conditions affiliated with different lean approaches and alternative strategies for performance improvement.

\section{LOST IN TRANSITION}

Despite heavy promotion in the professional press and national and global lean construction networks, lean construction has not featured strongly in the peer reviewed journals. The comparatively few articles that have been published have addressed specific aspects of the concept, (e.g. Ballard \& Howell 1998; 2003a; Arbulu et al. 2003; Tommelein et al. 1999; Vrijhoef \& Koskela 2000; Formoso et al. 2002a; 2002b; Ballard et al. 2003; Choo et al. 2004; Tsao et al. 2004; Elfving et al. 2005; Gil et al. 2005; Paez et al. 2005; Lapinski et al. 2006; Jørgensen \& Emmitt, 2008). The absence of articles in 
the peer reviewed journals is especially significant when considering the broad scope of the field. A small number of research reports and doctoral theses have also investigated specific aspects of lean construction (e.g. dos Santos 1999; Ballard 2000a; CIB 2002; CII 2004; Tzortzopoulos 2004; Tsao 2005, Jørgensen 2006).

The vast majority of publications on lean construction are conference papers from the annual conferences of The International Group for Lean Construction (IGLC). This is an important forum for exchange of ideas within the lean construction community of practitioners and academics. The proceedings comprise a wide range of papers, from meticulous research at one end of the scale to personal opinion at the other; and although this might be expected from such a forum, in the context of this literature review the variance in quality is problematic. However, since this is an important melting pot for ideas it would be inappropriate to disregard this resource out of hand, especially when considering the modest number of journal articles within the field. Indeed, a review of the proceedings helps to reveal a number of characteristics. First, there is an overriding positive bias to the papers, which mainly describe or prescribe significant improvements in performance. There is very little evidence of critical debate. Second, many papers have a tendency to be self-referential, based largely on other IGLC publications or on a limited range of titles on construction management, production control and popular management literature. Third, the critical research findings from the lean manufacturing/production field are missing.

In transferring lean to construction it is intriguing that the critical literature has been left behind. Whether or not this is a deliberate policy or simply an oversight is impossible to tell only from a literature review. Lean production and manufacturing literature tackles a wide range of factors that are important to the philosophy and implementation of lean methods, as highlighted in Koskela's (1992) seminal work. Even if one accepts that the context is different, it is still crucial to address the shortcomings of lean manufacturing and discuss/challenge them in the context of temporary construction projects. To simply ignore empirical research findings from lean manufacturing and production exposes the lean construction field to criticism and undermines its credibility. A point exploited by Green on several occasions (Green 1999a; 1999b; 2000; 2002; Green \& May 2005).

There has been little reaction to Green's well argued criticism (indeed Green's work is notable by its absence in the lean construction literature), which is curious given the zeal with which the benefits of lean construction are promoted. One exception is a direct repost by Howell \& Ballard (1999), who argue that lean is a positive phenomenon and that the adoption of lean in construction does not necessarily lead to negative issues. Interestingly, they fail to address Green's concern about the reluctance of the lean construction community to embrace the critical research literature. It is, however, not proven that negative impacts of lean production necessarily transfer to construction. Some studies have revealed how the application of lean practices had a deteriorating effect on workers' conditions in manufacturing, but context must be considered before concluding that outcomes of lean implementation, positive or negative, can be generalised across all business sectors. Research into the possibilities for construction to benefit from lean approaches while avoiding negative impacts, as called for by Howell \& Ballard (1999), is still to be addressed. 
The question about an appropriate fundamental approach for the development of a production management theory has been addressed in a number of publications (e.g. Koskela 2000; Koskela et al. 2004; Koskela \& Ballard 2006). Economics-based approaches to managing projects through decomposition of elements, cost and transactions are criticised for offering an inappropriate basis for theory development since they do not address directly the transformation, flow and value perspectives of production which Koskela (2000) argued to be central for understanding the production phenomenon. It is argued that a theory of project management should instead be based primarily on theories of production. Responding to a call from Koskela et al. (2004) and Koskela \& Ballard (2006) to engage in a discussion on these issues Winch (2005; 2006) argues that, on its own, a production-based management approach will be insufficient since it does not address vital contextual issues of transaction costs, market functions and intra- and inter-organisational business processes of the supply chain. Winch (2006) also argues that lean construction builds on a unitary concept of value deriving from quality management, which he concludes is inadequate for developing methods for ensuring that incentives are aligned both within the project coalition of interests and between the project coalition and external interests. While acknowledging that the work on lean construction has contributed to the understanding of the project management field Winch (2006) concludes that the proposed dichotomy between theories of economics and theories of production is not meaningful.

An important observation is that implicitly Winch argues from a position of lean construction narrowly understood as building on a theoretical element constituted by the TFV model (Koskela 2000) and practical application through the framework of the Lean Project Delivery System (Ballard et al. 2002). Such limitation is arguably regrettable, but understandable within the confines of a journal article when considering the absence of a shared definition/understanding of lean construction.

\section{CONCLUSIONS AND RECOMMENDATIONS}

Comparing the lean manufacturing and the lean construction research literature it is evident that that first field is considerably more developed than the second. The literature relating to lean production and manufacturing has a certain maturity, in that there is evidence of informed and critical debate within the peer reviewed journals. In particular, it is the critical and informed debate that appears to have been slow to develop within the lean construction literature. Similarly, a coherent philosophy for lean construction has not yet been developed. This may simply reflect a slower development of the construction literature compared with lean production and manufacturing (one could argue that it is difficult to enter into informed debate when so little research has been published in the peer reviewed journals); or it could be indicative of a reluctance to tackle some of the underlying weaknesses of the lean production approach. Similarly, the difference between the bodies of literature could be related to the fact that some of the most critical arguments are not relevant to a construction context; however, this cannot be taken for granted and needs to be confirmed or refuted through research.

In the transition of lean from manufacturing to construction the process losses appear to be related mainly to the critical aspects and the challenges surrounding the practical application to a different context. The picture is blurred by diverse interpretations of 
ideas and concepts (similar to the lean manufacturing literature) and the absence of a generally shared/accepted system of terminology is an obstacle for focussed debate. The original concept of delivering value to a specific single end customer is also highly problematic when considering the built product in a whole-life context.

Some 'back to basics' discussion on what is meant and implied by the terms 'lean construction' and 'customer value' would be helpful in establishing greater clarity. In particular the role of designers and the effect of early design decisions on construction activities requires further research. The lack of empirical research findings in the peer reviewed journals is currently a weakness of the lean construction field. So too is the failure to recognise the empirical research findings from the lean manufacturing and production literature, especially the findings that are not supportive of lean superiority. Confronting and learning from known weaknesses and the potential disadvantages of lean manufacturing should help, rather than hinder, the future development of lean construction. Critical discussion on the preconditions for, and limits of, lean application to construction would greatly help to advance the body of knowledge concerning practical application of lean to the built environment. Present industry attention illustrates the need for a better basis from which to offer impartial advice to practitioners based on empirical research findings, clear constructs, informed debate and constructive criticism.

\section{REFERENCES}

Abrahamson, E. (1996) Management Fashion. Academy of Management Review, Vol. 21 (1), pp. 254-285.

Alarcón, L., (ed.) (1997) Lean Construction. A.A. Balkema Publishers, Rotterdam, The Netherlands.

Alarcón, L., Diethelm, S., Rojo, O. \& Calderon, R. (2005) Assessing the Impacts of Implementing Lean Construction. In: Proceedings of the $13^{\text {th }}$ Annual Conference of the International Group for Lean Construction (IGLC-13), Sydney, July, pp. 387-393.

Alves, T.C.L. \& Tommelein, I.D. (2004) Simulation of Buffering and Batching Practices in the Interface Detailing-Fabrication.-Installation of HVAC Ductwork. In: Proceedings of the $12^{\text {th }}$ Annual Conference of The International Group for Lean Construction, Elsinore, Denmark.

Arbulu, R.J., Tommelein, I.D., Walsh, K.D. \& Hershauer, J.C. (2003) Value stream analysis of a re-engineered construction supply chain. Building Research \& Information, 31(2), p. 161-171. Spon Press.

Ballard, G. (1993) Lean construction and EPC performance improvement. $1^{\text {st }}$ International Workshop on Lean Construction, Espoo, Finland. (Reprinted in Alarcón, L. (1997), pp. 79-91).

Ballard, G. (2000a) The Last Planner System of Production Control, PhD Thesis, University of Birmingham, UK. 
Ballard, G. (2002) Managing work flow on design projects: a case study, Engineering, Construction and Architectural Management, 9(3), 284-291.

Ballard, G. (2005) Construction: One Type of Project-Based Production System. In: Proceedings SCRI Forum Event Lean Construction: The Next Generation. January $19^{\text {th }}$, SCRI, University of Salford.

Ballard, G., Harper, N., \& Zabelle, T. (2003). Learning to See Work Flow: Application of Lean Production Concepts to Precast Concrete Fabrication. Journal of Engineering, Construction and Architectural Management, 10(1), pp. 6-14. Blackwell.

Ballard, G. \& Howell, G. (1998) Shielding Production: Essential Step in Production Control. Journal of Construction Engineering and Management, 124, p.11-17.

Ballard, G \& Howell, G.A. (2003a) Lean project management. Building Research and Information, vol. 31(2), pp. 119-133, Spon Press.

Ballard. G. \& Howell, G.A. (2003b) An Update on Last Planner. In: Proceeding For the $11^{\text {th }}$ Annual Conference of the International Group for Lean Construction (IGLC-11), Blacksburg, Va, USA, July 2003.

Ballard, G., Koskela, L., Howell, G.A. \& Tommelein, I.D. (2005) Discussion of "Improving Labor Flow Reliability for Better Productivity as Lean Construction Principle” by H. Randolph Thomas, Michael J. Horman, R. Edward Minchin Jr. and Dong Chen". Discussion and Closures in the Journal of Construction Engineering and Management, ASCE, May, pp. 615-616.

Ballard, G., Tommelein, I, Koskela, L. \& Howell, G. (2002) Lean construction tools and techniques. In Hellingsworth, B., Best, R. \& de Valence, G. (eds.): Design and Construction: Building in Value, pp. 227-255. Elsevier.

Benders, J. (1999) Tricks and trucks: a case study of organization concepts at work. The International Journal of Human Resource Management, Vol. 10(4), pp. 624-637.

Benders, J. \& van Bijsterveld, M. (2000) Leaning on lean: the reception of a management fashion in Germany. New Technology, Work and Employment, Vol. 15:1, pp. 50-64.

Berggren, C. (1992) Alternatives to Lean Production: Work Organization in the Swedish Auto Industry. ILR Press, Ithaca, New York.

Berggren , C. (1993). Lean Production - The End of History? Work, Employment and Society, Vol. 7, No. 2, 1993.

Boyer, R. \& Freyssenet, M. (2002) The productive models: the conditions of profitability. Palgrave MacMillan, New York. 
Briggs, P. (1988) The Japanese at work: illusions of the ideal. Industrial Relations Journal, Vol. 19(1), pp. 24-30.

CIB (2002) Benchmarking of Labor-Intensive Construction Activities: Lean Construction and Fundamental Principles of Workforce Management, CIB Publication 276 (by Thomas, R., Horman, M., de Souza, U.E.L. \& Zavrski, I.), International Council for Research and Innovation in Building and Construction (CIB). Rotterdam, The Netherlands.

CII (2004) Application of Lean Manufacturing Principles to Construction. A Report to the Construction Industry Institute (CII \#191). Diekmann, J., Krewedl, M., Balonick, J., Stewart, T. \& Won, S. The University of Texas at Austin.

Choo, H.J., Hammond, J., Tommelein, I.D., Austin, S.A. \& Ballard, G. (2004) DePlan: a tool for integrated design management. Automation in Construction, Vol. 13 (2004), pp. 313-326.

Cooney, R. (2002) Is "lean” a universal production system?: Batch production in the automotive industry. International Journal of Operations \& Production Management, Vol. 22(10) pp. 1130-1147.

Cooper, R. \& Slagmulder, R (1999) Supply Chain Development for the Lean Enterprise. The Institute of Management Accountants Foundation for Applied Research, Montvale New Jersey, USA. Productivity Press, Portland, Oregon.

Cusumano, M.A. (1994) The Limits of “Lean”. Sloan Management Review, Summer 1994, pp. 27-32.

DETR (1998) Rethinking Construction, Department of the Environment, Transportation and the Regions, London.

Dohse, K., Jürgens, U. \& Malsch, T, (1985) From ”Fordism” to ”Toyotism”? The Social Organization of the Labor Process in the Japanese Automobile Industry. Politics and Society, Vol. 14(2), pp. 115-146.

Elfving, J.A., Tommelein, I.D. \& Ballard, G. (2005) Consequences of competitive bidding in project-based production. Journal of Purchasing \& Supply Management, Vol. 11 (2005), pp. 173-181.

Fernie, S. And Thorpe, A. (2007) Exploring change in construction: supply chain management, Engineering, Construction and Architectural Management, 14:4, pp319333.

Freire, J. \& Alarcón, L.F. (2002) Achieving Lean Design Process: Improvement Methodology. Journal of Construction Engineering and Management, Vol. 128(3), pp. 248-256. 
Formoso, C.T., dos Santos, A. \& Powell, J.A. (2002a) An Exploratory Study on the Applicability of Process Transparency in Construction Sites. Journal of Construction Research, Vol. 3(1), pp. 35-54.

Formoso, C.T., Soibelman, L., De Cesare, C. \& Isatto, E.L. (2002b) Material Waste in Building Industry: Main Causes and Prevention. Journal of Construction Engineering and Management, July/August 2002, pp. 316-325.

Gil, N., Tommelein, I.D., Stout, A. \& Garrett, T. (2005) Embodying Product and Process Flexibility to Cope with Challenging Project Deliveries. Journal of Construction Engineering and Management, ASCE April, pp. 439-448.

Green, S. D. (1999a) The missing arguments of lean construction. Construction Management and Economics, Vol. 17, pp. 133-137.

Green, S.D. (1999b) The Dark Side of Lean Construction: Exploitation and Ideology. In: Proceedings for the $7^{\text {th }}$ Annual Conference of the International Group for Lean Construction (IGLC-7), Berkeley, CA, USA

Green, S. D. (2000). The Future of Lean Construction - A Brave New World. In: Proceedings for the $8^{\text {th }}$ Annual Conference on Lean Construction (IGLC-8), Brighton, UK.

Green, S.D. (2002) The Human Resource Management Implications of Lean Construction: Critical Perspectives and Conceptual Chasms. Journal of Construction Research, 3(1), pp147-166.

Green, S.D. \& May, S.C. (2005) Lean construction: arenas of enactment, models of diffusion and the meaning of 'leanness', Building Research \& Information, 33(6), 498511.

Hines, P., Holweg, M. \& Rich, N. (2004) Learning to evolve; A review of contemporary lean thinking. International Journal of Operations \& Production Management, Vol. 24 (10) pp. 994-1011.

Howell, G. \& Ballard, G. (1999) Bringing Light to the Dark side of Lean Construction: A Response to Stuart Green. In: Proceedings for the $7^{\text {th }}$ Annual Conference of the International Group for Lean Construction (IGLC-7), Berkeley, CA, USA.

Howell, G.A., Ballard, G., Tommelein, I.D. \& Koskela, L. (2004) Discussion of "Reducing Varibility to Improve Performance as a Lean Construction Principle" by H. Randolph Thomas, Michael J. Horman, Ubiraci Espinelli Lemes de Souza, and Ivica Zavřski. Discussion and Closures in the Journal of Construction Engineering and Management, ASCE, March/April, pp. 299-300.

Johansen, E., Porter, G. \& Greenwood, D. (2004) Implementing Lean: UK Culture and System Change. In: Proceedings for the $12^{\text {th }}$ Annual Conference of the International Group for Lean Construction (IGLC-12), Elsinore, August. 
Jørgensen, B. (2006) Integrating Lean Design and Lean Construction: Processes and Methods. Ph.D. thesis, Technical University of Denmark, Department of Civil Engineering, 286p.

Jørgensen, B.\& Emmitt, S. (2008) Investigating the implementation of design and construction from a 'lean' perspective, Construction Innovation: Information, Process, Management, Vol.8:2.

Jürgens, U. (1995) Lean Production in Japan: Myth and Reality. In Littek, W. \& Charles, T. (eds.) (1995) The New Division of Labour: Emerging Forms of Work Organisation in International Perspective, pp. 349-366. Walter de Gruyter, New York.

Katayama, H. \& Bennett, D. (1996) Lean production in a changing competitive world: a Japanese perspective. International Journal of Operations \& Production Management, Vol. 16(2), pp. 8-23.

Kenley, R. (2004) Project Micromanagement: Practical Site Planning and Management of Work Flow. In: Proceedings for the $12^{\text {th }}$ Annual Conference of the International Group for Lean Construction (IGLC-12), Elsinore, August.

Kieser, A. (1997) Rhetoric and Myth in Management Fashion. Organization, Vol. 4(1), pp. 49-74.

Koskela, L. (1992) Application of the New Production Philosophy to Construction, Tech. Report No. 72, CIFE, Stanford University, CA.

Koskela, L. (1993) Lean production in construction. $1^{\text {st }}$ International Workshop on Lean Construction, Espoo, Finland. (Reprinted in Alarcón, L. (1997), pp. 1-9).

Koskela, L. (2000) An Exploration Towards a Production Theory and its Application to Construction, VTT, Espoo, Finland.

Koskela, L. (2001) On New Footnotes to Shingo. In: Proceedings for the $9^{\text {th }}$ Annual Conference of the International Group for Lean Construction (IGLC-9), Singapore.

Koskela, L. \& Ballard, G. (2006) Should project management be based on theories of economics or production? Building Research and Information, Vol. 34(2), pp. 154-163.

Koskela, L. Ballard, G. \& Howell, G. (2004) Project Management Reconceived from a Production Perspective. Proceedings, CIB World Congress, Toronto.

Koskela, L., Ballard, G. \& Tanhuanpää, V.P. (1997) Towards Lean Design Management. In: Proceedings for the $5^{\text {th }}$ Annual Conference of the International Group for Lean Construction (IGLC-5), Gold Coast, Australia. 
Koskela, L., Howell, G., Ballard, G. \& Tommelein, I. (2002) The foundations of lean construction, In Hellingsworth, B., Best, R. \& de Valence, G. (eds.): Design and Construction: Building in Value, Elsevier, 211-226

Koskela, L. \& Kagioglou, M. (2005) On the Metaphysics of Production. In: Proceedings of the $13^{\text {th }}$ Annual Conference of the International Group for Lean Construction, Sydney, July.

Lapinski, A.R., Horman, M.J. \& Riley, D.R. (2006) Lean Processes for Sustainable Project Delivery. Journal of Construction Engineering and Management, ASCE October, pp. 1083-1091.

Lewis, M.A. (2000) Lean production and sustainable competitive advantage. International Journal of Operations \& Production Management, Vol. 20(8), pp. 959978.

Lillrank, P. (1995) The Transfer of Management Innovations from Japan. Organization Studies, 16/6 p. 971-989.

Miller, C.J.M., Packham, G.A. \& Thomas, B.C. (2002) Harmonization between Main Contractors and Subcontractors: a Prerequisite for Lean Construction? Journal of Construction Research, Vol. 3(1), pp. 67-82.

Morris, J. \& Wilkinson, B. (1995) The Transfer of Japanese Management to Alien Institutional Environments. Journal of Management Studies, Vol. 32:6 (ed.), pp. 719730, November 1995.

Ohno, T (1988). The Toyota Production System: Beyond Large-Scale Production. Productivity Press, Portland, Oregon.

Paez, O., Salem, S., Solomon, J. \& Genaidy, A. (2005) Moving from Lean Manufacturing to Lean Construction: Towards a Common Sociotechnological Framework. Human Factors and Ergonomics in Manufacturing, Vol. 15(2), pp. 233-245.

dos Santos, A., (1999). Application of flow principles in the production management of construction sites. PhD Thesis. School of Construction and Property Management, University of Salford, England.

Shingo, S. (1988). Non-Stock Production: The Shingo System for Continuous Improvement. Productivity Press Inc., Cambridge, Massachusetts.

Shingo, S. (1989) A Study of the Toyota Production System From an Industrial Engineering Viewpoint (rev. ed.). Productivity Press Inc., Cambridge, Massachusetts. (1 $1^{\text {st }}$ ed. 1981).

Sullivan, J.J. (1992) Japanese Management Philosophies: From the Vacuous to the Brilliant. California Management Review, 34 (2), pp. 66-87. 
Tanskanen, K., Wegelius, T. \& Nyman, H. (1993) New tools for lean construction. $1^{\text {st }}$ International Workshop on Lean Construction. Espoo, Finland. (Reprinted in Alarcón, L. (1997), pp. 335-341).

Thomas, H.R., Horman, M.J., de Souza, U.E.L. \& Zavřski, I. (2002) Reducing Variability to Improve Performance as a Lean Construction Principle. Journal of Construction Engineering and Management, ASCE March/April pp. 144-154.

Thomas, H.R., Horman, M.J., Minchin Jr., R.E. \& Chen, D. (2003) Improving Labor Flow Reliability for Better Productivity as Lean Construction Principle. Journal of Construction Engineering and Management, ASCE May/June, pp. 251-261.

Thomas, H.R., Horman, M.J., de Souza, U.E.L. \& Zavřski, I. (2004) Closure to "Reducing Varibility to Improve Performance as a Lean Construction Principle" by H. Thomas, H.R., Horman, M.J., de Souza, U.E.L. \& Zavřski, I. Discussion and Closures in the Journal of Construction Engineering and Management, ASCE, March/April, pp. 300-301.

Thomas, H.R., Horman, M.J., Minchin Jr., R.E. \& Chen, D. (2005) Closure to "Reducing Varibility to Improve Performance as a Lean Construction Principle" by H. Randolph Thomas, Michael J. Horman, Ubiraci Espinelli Lemes de Souza, and Ivica Zavřski. Discussion and Closures in the Journal of Construction Engineering and Management, ASCE, May, pp. 616-617.

Tommelein, I.D. (1999) Lean construction experiments using discrete-event simulation: techniques and tools for process re-engineering? International Journal of ComputerIntegrated Design and Construction, CIDAC, Special issue on Construction Process Re-engineering, Vol. 1(2), pp. 53-63.

Tommelein, I.D., Riley, D.R. \& Howell, G.A. (1999) Parade Game: Impact of Flow Variability on Trade Performance. ASCE, Journal of Construction Engineering and Management, 125(5) pp. 304-310.

Tsao, C. (2005) Use of Work Structuring to Increase Performance of Project-Based Production Systems. Ph.D. thesis, University of California at Berkeley.

Tsao, C., Tommelein, I., Swanlund, E. \& Howell, A. (2004) Work Structuring to Achieve Integrated Product-Process Design. Journal of Construction Engineering and Management, ASCE November/December.

Tzortzopoulos, P. (2004) The Design and Implementation of Product Development Process Models in Construction Companies. Ph.D. thesis, University of Salford, UK.

Vrijhoef, R. \& Koskela, L. (1999) Roles of Supply Chain Management in Construction. In: Proceedings for the $7^{\text {th }}$ Annual Conference of The International Group for Lean Construction (IGLC-7). Berkeley, California. 
Vrijhoef, R. \& Koskela, L. (2000) The four roles of supply chain management in construction. European Journal of Purchasing \& Supply Management, Vol. 6, pp. 169178.

Vrijhoef, R \& Koskela, L. (2005) A Critical Review of Construction as a Project-based Industry: Identifying Paths Towards a Project-independent Approach to Construction. In: Proceedings of the CIB Joint Symposium, 'Combining Forces - Advancing Facilities Management and Construction through Innovation’. VTT, Helsinki.

Vrijhoef, R.; Koskela, L. \& Voordijk, H. (2003). Understanding Construction Supply Chains: A Multiple Theoretical Approach to Inter-Organizational Relationships in Construction. In: Proceedings for the 11th Annual Conference of the International Group for Lean Construction (IGLC-11), Blacksburg, Virginia, USA.

Wilkinson, B., Morris, J. \& Munday, M. (1995) The Iron Fist in the Velvet Glove: Management and Organization in Japanese Manufacturing Transplants in Wales. Journal of Management Studies, Vol. 32(6), pp. 819-830.

Wilkinson, B. \& Oliver, N. (1989) Power, Control and the Kanban. Journal of Management Studies, Vol. 26(1), pp. 47-58.

Williams, K., Haslam, C., Johal, S., Williams, J., Adcroft, A. \& Willis, R. (1995) Management Practice or Structural Factors: The Case of America versus Japan in the Car Industry. Economic and Industrial Democracy, Vol. 16, pp. 9-37.

Winch, G.M. (2005) Construction as Production by Projects. In S. Kazi (ed.): Learning from Experience: New Challenges, Theories and Practices in Construction. In: Proceedings of the CIB Joint Symposium, 'Combining Forces - Advancing Facilities Management and Construction through Innovation'. VTT, Helsinki, Vol. 7, pp. 25-41.

Winch, G.M. (2006) Towards a theory of construction as production by projects. Building Research and Information, Vol. 34(2), pp. 164-174.

Womack, J.P. \& Jones, D.T. (1996) Lean Thinking: banish waste and create wealth in your corporation, Simon \& Schuster, New York.

Womack, J.P., Jones, D.T., \& Roos, D. (1990) The Machine That Changed the World: The Story of Lean Production, Harper Business, New York. 
Europe, AUS,

USA

Japan

Latin America,
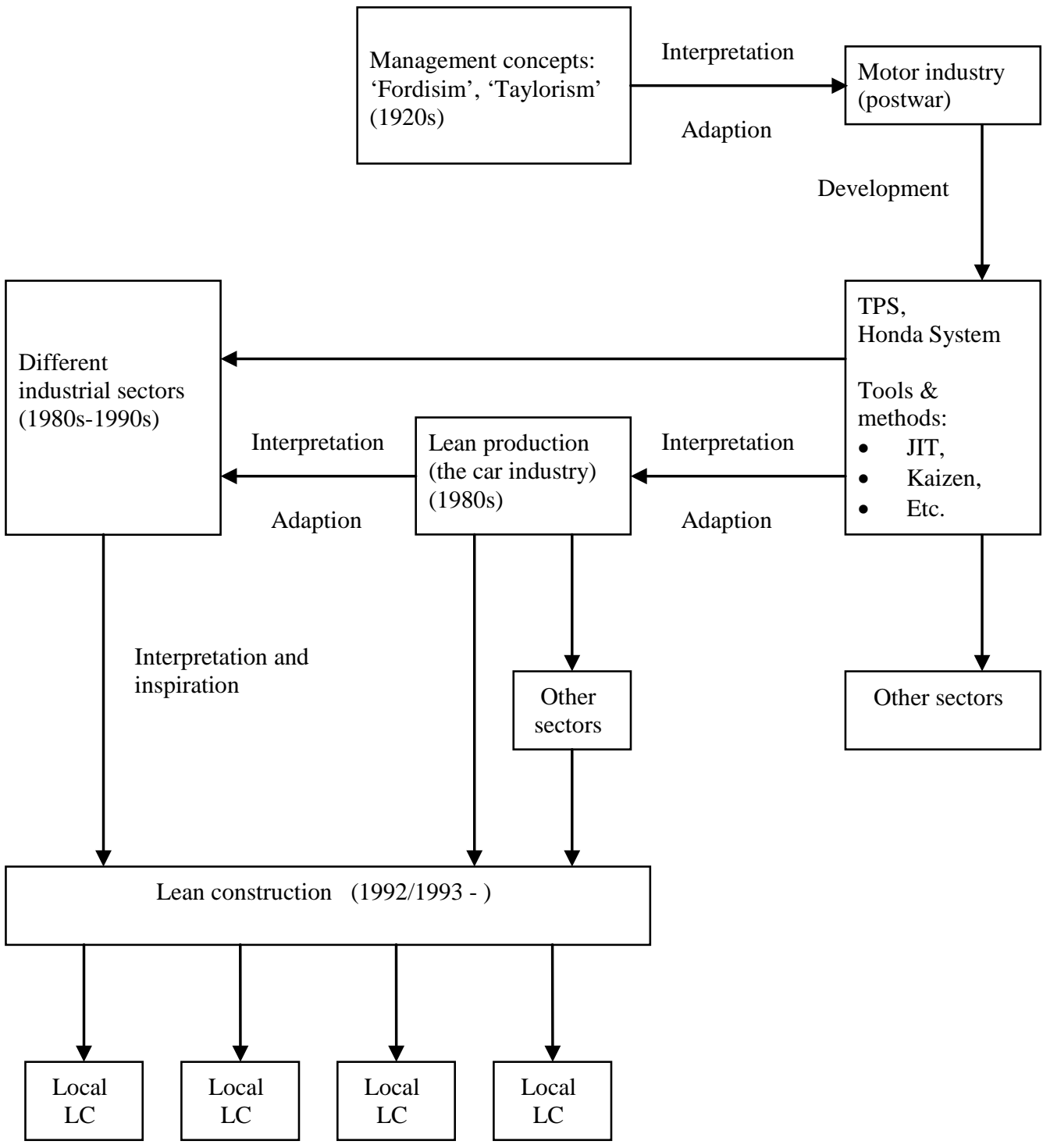

Figure 1: Schematic overview of the diffusion of lean production. - Schematic overview, only main ways (arrows) shown. 